\title{
Historical and Hypothetical Future Sedimentation and Water Storage in Kajakai Reservoir, Central Afghanistan
}

\section{Summary}

Sedimentation has reduced water storage in Kajakai Reservoir. If current sedimentation rates continue, hypothetical future reservoir water volumes at the spillway elevation of 1,033.5 meters could be reduced about 22 percent from 2006 to 2057 . Even if the spillway elevation is raised to 1,045 meters, a severe drought could result in large multiyear irrigation-supply deficits in which reservoir water levels remain below 1,022 meters for more than 4 years. Hypothetical climate change and sedimentation could result in greater water-supply deficits. The chance of having sufficient water supplies in Kajakai Reservoir during the worst month is about 47 percent.

\section{Introduction}

The management of natural resources, especially water, is important for improving the economy of Afghanistan. Irrigation is essential to many crops in Afghanistan; therefore, people commonly live close to rivers and reservoirs to maintain easy access to water (Favre and Kamal, 2005). During periods of low water levels, people moved to the shores and onto the sediment beds of Kajakai Reservoir on the Helmand River in central Afghanistan to farm and possibly reside (Blue, 2006). Proposed economic development and future improvements to Kajakai Dam may include increases in reservoir storage for increased hydropower production and downstream irrigation. However, increased water volumes and water levels in Kajakai Reservoir could necessitate the resettlement of people who live near the reservoir. This fact sheet, which is based on information from Vining and Vecchia (2007), is intended to provide Afghanistan authorities with information on historical and hypothetical future sedimentation and water storage in Kajakai Reservoir that could be used to make decisions concerning reservoir operation and economic development along the Helmand River.

\section{Central Afghanistan and Kajakai Reservoir}

Central Afghanistan is mostly hilly to mountainous arid rangeland and a small percentage of the area is devoted to cultivated agriculture (Favre and Kamal, 2004, 2005). Annual precipitation ranges from about 100 to 400 millimeters and falls mostly at higher elevations during winter and spring (Favre and Kamal, 2004). A prolonged drought from about 1999 to 2005, which likely reduced streamflows in the Helmand River and runoff to reservoirs, resulted in the drying of wetlands on the Afghanistan-Iran border (Whitney, 2006).
Kajakai Reservoir, which is a major water body in central Afghanistan, formed after the completion of Kajakai Dam on the Helmand River in 1952 (Perkins and Culbertson, 1970; fig. 1). The main purpose of the reservoir is to supply irrigation water to areas downstream from Kajakai Dam. Hydropowergeneration facilities were added to the dam in 1975. Currently (2007), Kajakai Dam impounds water to the spillway elevation of 1,033.5 meters. Proposed improvements to the spillway include the construction of gates to impound water to an elevation of 1,045 meters (U.S Army Corps of Engineers, written commun., 2005).

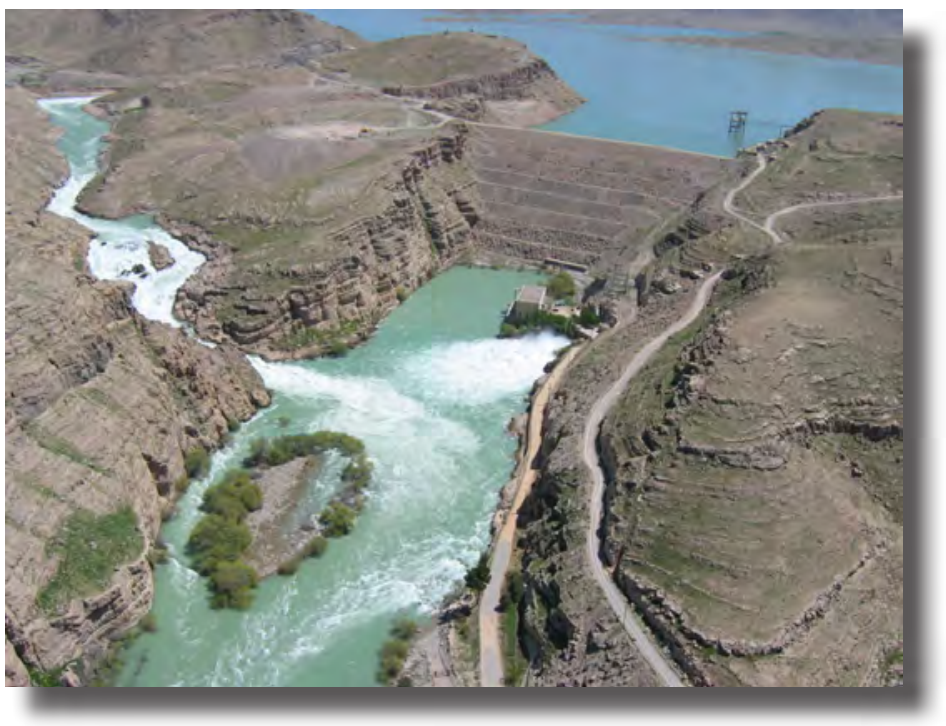

Kajakai Reservoir, Kajakai Dam complex, and spillway. 


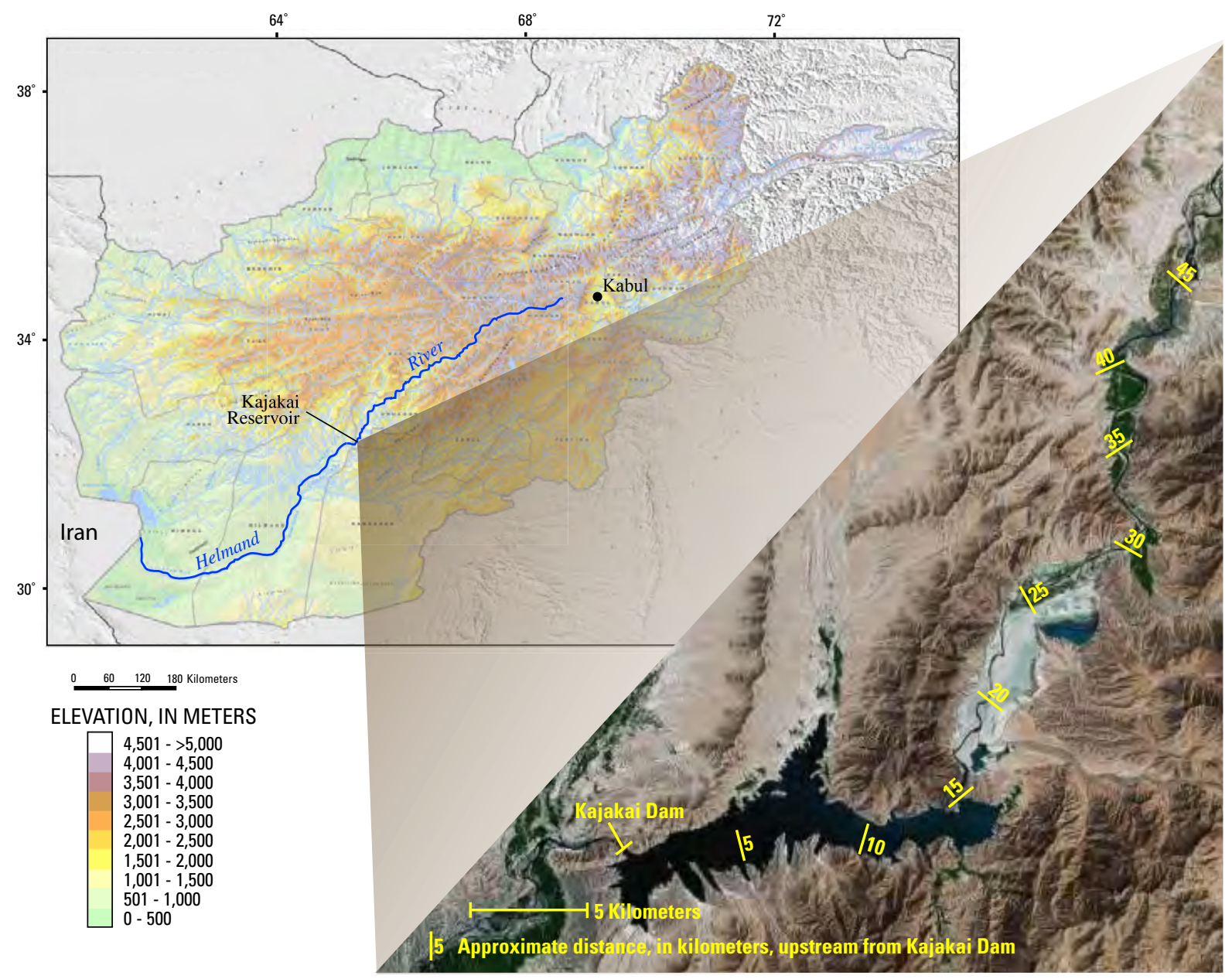

Figure 1. Location of Kajakai Reservoir, central Afghanistan (adapted from Afghanistan Information Management Services, 2006, and U.S. Geological Survey Landsat imagery obtained from Google Earth in 2007).

\section{Historical and Hypothetical Future Sedimentation in Kajakai Reservoir}

Sediment deposition has occurred in Kajakai Reservoir since the reservoir formed. A topographic survey in 1953 indicated Kajakai Reservoir had an original volume of about 1,844 million cubic meters at the current spillway elevation of 1,033.5 meters (Perkins and Culbertson, 1970). In 1968, a sedimentation survey indicated the reservoir had lost about 7 percent of its volume to about 1,715 million cubic meters (Perkins and Culbertson, 1970). By 2005, sedimentation had likely reduced the reservoir volume by about 26 percent to an estimated 1,360 million cubic meters at the current spillway elevation (Whitney, 2006).

Landsat images taken in about 2000 and obtained from Google Earth in 2007 (fig. 1) indicated possible sedimentation upstream from a reservoir narrows (near kilometer 15) where farming plots and possible settlements appear (upstream from kilometer 25). The combination of satellite photography and past reservoir surveys indicated the elevation of sediments in the far northern portion of the reservoir might at least equal the spillway elevation of 1,033.5 meters. Using this information, a reservoir sediment profile for 2006 was estimated (fig. 2). For 2006, the reservoir incremental volume between elevations of 1,030 and 1,045 meters was estimated to be about 1,140 million cubic meters (fig. 3), which compares well to an estimated
1,230 million cubic meters determined by using a digital elevation model (Blue, 2006).

\section{Historical and Hypothetical Future Water Storage in Kajakai Reservoir}

Historical water volumes in Kajakai Reservoir, calculated from published and estimated information (Perkins and Culbertson, 1970; Whitney, 2006), indicate a storage loss of about 365 million cubic meters (about 21 percent) from 1968 to 2006 at the current spillway elevation (fig. 3). If sedimentation into the reservoir continues at the historical rate, hypothetical future reservoir water volumes at the current spillway elevation could be reduced another 22 percent from 2006 to 2057 (fig. 3).

Investigations of hypothetical future water storage in Kajakai Reservoir included a spillway elevation of 1,045 meters, continued sedimentation, climate change, and irrigation development (Vining and Vecchia, 2007). Some studies suggest that precipitation decreases of about 10 percent (Milly and others, 2005) and temperature increases of about 2 degrees Celsius (Vining and Vecchia, 2007) could occur in central Afghanistan by about 2057 . In addition, irrigated area below Kajakai Reservoir could increase from about 234,000 hectares (Favre and Kamal, 2004) to about 420,000 hectares (U.S. Army Corps of Engineers, written commun., 2005), resulting in a possible near doubling of irrigation demand. 


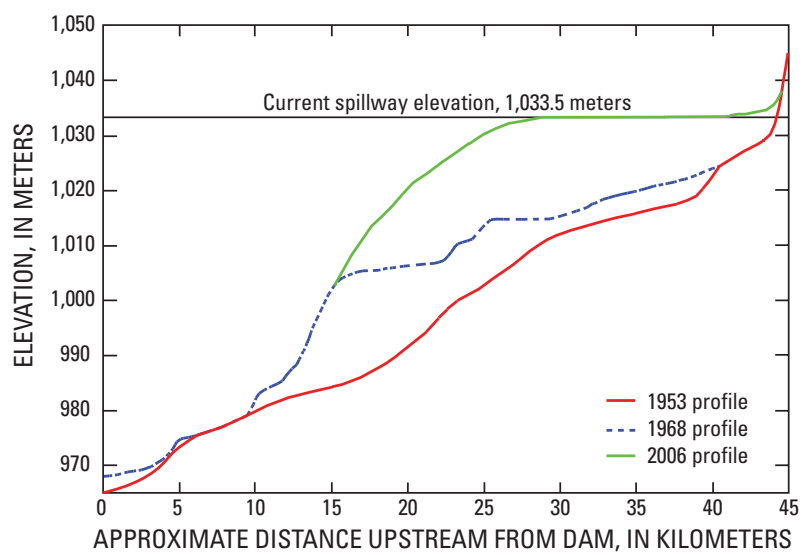

Figure 2. Kajakai Reservoir sediment profiles for 1953 and 1968, and estimated sediment profile for 2006 (adapted from Perkins and Culbertson, 1970).

Reservoir water levels initialized at the conservation elevation of 990 meters were used to investigate the effects of irrigation demand on hypothetical water-level probabilities during reservoir filling (Vining and Vecchia, 2007). Calculations using existing and doubled downstream irrigation demand indicate that the reservoir has about a 75-percent chance and about a 50-percent chance, respectively, of filling to 1,045 meters within 2 years (fig. 4). During a severe drought, however, large multiyear irrigation-supply deficits could occur in which water levels remain below 1,022 meters for more than 4 years before increasing to 1,045 meters (Vining and Vecchia, 2007). Although the chance of such a severe drought is estimated to be 1-in-100 during the next few years, the impacts of the drought on downstream agriculture could be substantial.

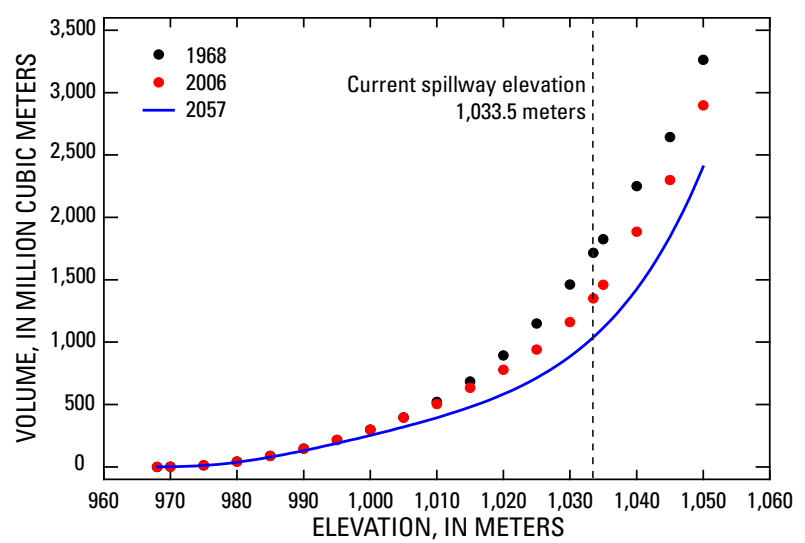

Figure 3. Published and estimated storage volumes for 1968 and 2006 for Kajakai Reservoir, and hypothetical storage volumes for 2057.

The effects of doubled downstream irrigation demand, hypothetical monthly temperature increases of 2 degrees Celsius, reservoir sedimentation estimated at 2057 levels, and 10 -percent decreases in monthly precipitation on hypothetical future water levels in Kajakai Reservoir indicate reservoir levels are likely to decline and supply deficits are more likely to occur (Vining and Vecchia, 2007). For example, with current sedimentation and climate conditions and doubled downstream irrigation demand, water-supply deficits in July would occur 10 percent of the time (once every 10 years, on average) compared to 28 percent of the time (more than once in 4 years, on average) with future sedimentation and potential climate change (fig. 5). In September and October, water-supply deficits would occur once every 5 years, on average, with current

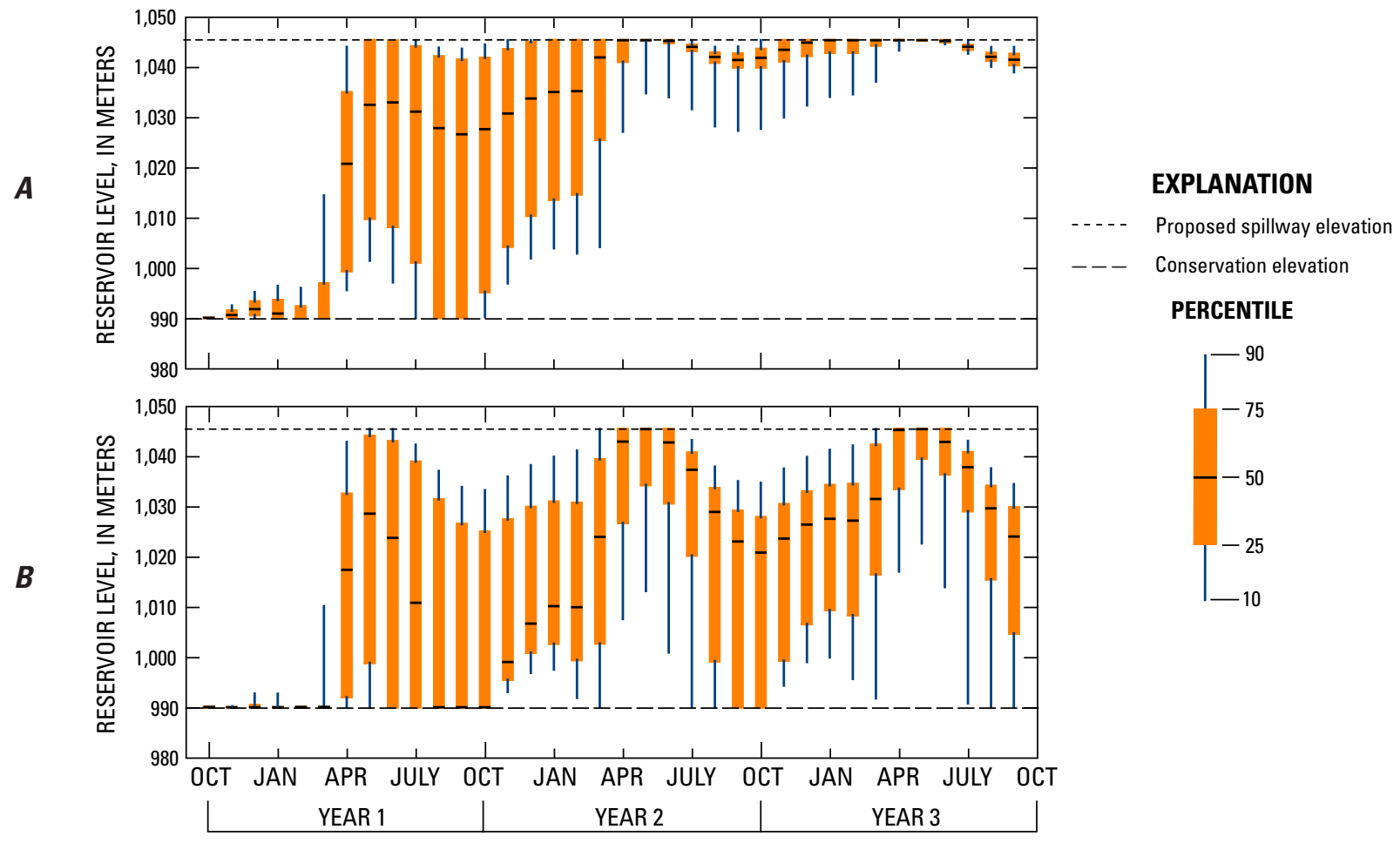

Figure 4. Percentiles of generated monthly reservoir levels for a 36-month conditional simulation period and an initial reservoir level of 990 meters assuming $A$, existing (2006) downstream irrigation demand and $B$, a doubling of downstream irrigation demand. 
sedimentation and climate conditions compared to about once every 2 years, on average, with future sedimentation and potential climate change. Stated another way, the chance of having sufficient water supplies in Kajakai Reservoir during the worst month (October) is about 47 percent.
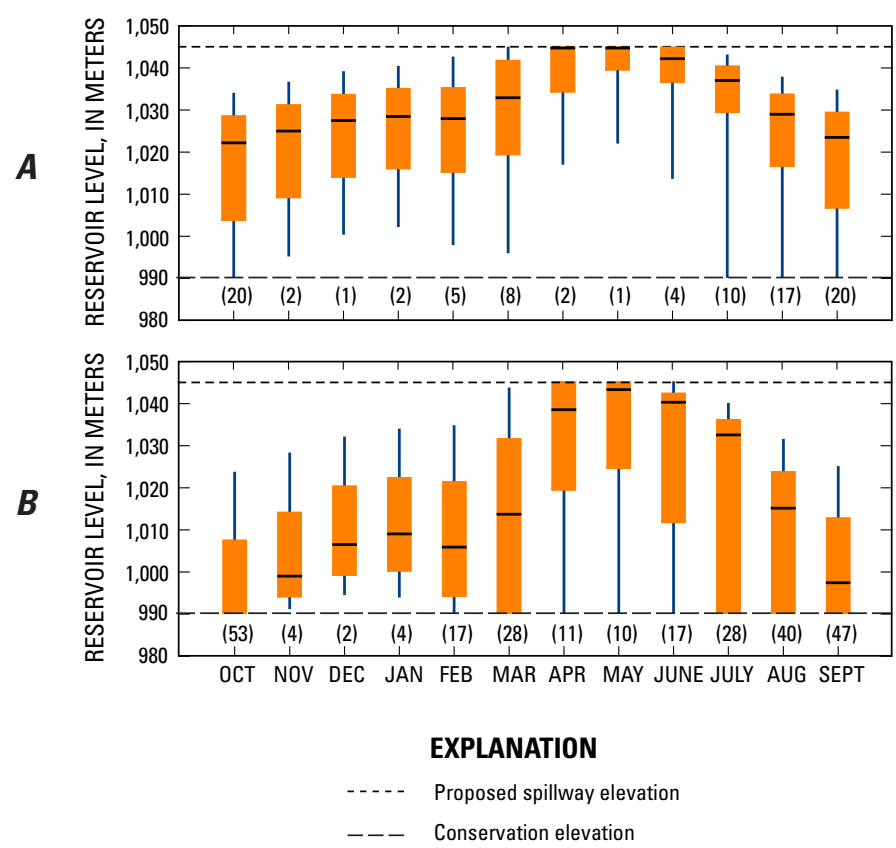

PERCENTILE

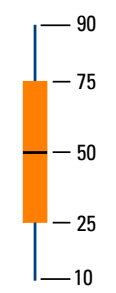

(20) Percent chance
of supply deficit

Figure 5. Percentiles of hypothetical monthly reservoir levels for $A$, conditions in 2006 but doubled downstream irrigation demand, and $B$, conditions in 2057 that include a 2-degree-Celsius increase in temperature, sedimentation estimated at 2057 levels, and a 10-percent decrease in precipitation and doubled downstream irrigation demand.

\section{—Kevin C. Vining and Aldo V. Vecchia}

\section{References}

Afghanistan Information Management Services, 2006, Afghanistan physical map, accessed May 2007 at http://www.aims.org.af

Blue, A.C., 2006, Kajakai Dam inundation study-Kajakai Dam and Reservoir, Helmand Province, Afghanistan: U.S. Army Corps of Engineers Report to U.S. Agency for International Development, September 2006, 23 p.

Favre, R., and Kamal, G.M., 2004, Watershed atlas of Afghanistan: Afghanistan Information Management Service, Kabul, Afghanistan, 183 p.

Favre, R., and Kamal, G.M., 2005, Watershed atlas of Afghanistan-Book 2, Watershed maps: Afghanistan Information Management Service, Kabul, Afghanistan, 145 p.

Milly, P.C.D., Dunne, K.A., and Vecchia, A.V., 2005, Global pattern of trends in streamflow and water availability in a changing climate: Nature, v. 438, no. 17 , p. 347-350.

Perkins, D.C., and Culbertson, J.K., 1970, Hydrographic and sedimentation survey of Kajakai Reservoir, Afghanistan: U.S. Geological Survey Water-Supply Paper 1608-M, 43 p.

Vining, K.C., and Vecchia, A.V., 2007, Water-balance simulations of runoff and reservoir storage for the Upper Helmand watershed and Kajakai Reservoir, central Afghanistan: U.S. Geological Survey Scientific Investigations Report 2007-5148, 16 p.

Whitney, J.W., 2006, Geology, water, and wind in the lower Helmand Basin, southern Afghanistan: U.S. Geological Survey Scientific Investigations Report 2006-5182, 40 p.

\section{USGS Afghanistan Project Product Number 176.}

This study was funded by Interagency Agreement 07C442100KB between the U.S. Agency for International Development and the U.S. Geological Survey.

Photographs courtesy of Donald C. Houk, advisor to the U.S Agency for International Development; Verne R. Schneider, U.S. Geological Survey; and John W. Whitney, U.S. Geological Survey.

Assistance in development of fact sheet courtesy Tara A. Banse 